\title{
Effects of Long-term Acid Suppressants with Ranitidine and Omeprazole on Gastric Mucosa
}

\author{
Alexander PC, Ramya S, Rajkumar Solomon T, Raja S, Priyadarshini M, Geetha R, Vijaya Srinivasan, \\ Jayanthi V
}

Department of Gastroenterology and Pathology, Stanley Medical College Hospital, and Global Health City, Chennai

\begin{abstract}
Background and objectives: Proton pump inhibitors are used widely for gastroesophageal reflux disease and ulcer type dyspepsia. Majority of the patients require long term medication. H2 receptor antagonist are also used for relief of symptoms. Though tachyphylaxis has been reported, symptom response is seen with long term use. The aim of the present study was to study the effects of long-term acid suppressants on gastric antral histology.

Methods: Patients who received long-term acid suppressants such as ranitidine and omeprazole for gastroesophageal reflux disease or dyspepsia were included. All of them had an antral biopsy for histology and H. pylori status at baseline, at 6 months and 12 months. Patients on acid suppressants for less than a year or on long-term non-steroidal anti inflammatory drugs were excluded from the study. The grading of gastritis was classified as chronic active gastritis, atrophic gastritis, intestinal metaplasia and dysplasia.

Results: Thirty patients received ranitidine and 28 omeprazole. In H. pylori positive group, the median duration of ranitidine and omeprazole were 3 years (1.5 to 8 years) and 4 years (1 to 10 years) respectively. Two thirds of patients had chronic active gastritis (ranitidine: 35.5\%; omeprazole:26.6\%); 10 had gastric atrophy (ranitidine: 6.6\%; omeprazole:15.5\%) and 7 had intestinal metaplasia (ranitidine $4.4 \%$; omeprazole11.1\%). Four of the 10 patients on omeprazole showed progression of histology as against only one of the 13 patients on ranitidine at one year of follow up. In omeprazole pylori negative patients, the median duration of ranitidine and omeprazole was 2.5 years (range 1 to 6 years) and 3 years (range 2 to 7 years) respectively. Irrespective of the acid suppressants, the baseline histology was either chronic active gastritis (78.5\%) or gastric atrophy $(21.5 \%)$. None had intestinal metaplasia. Also there was no progression in histology staging during the followup.

Conclusions: Long-term acid suppressants irrespective of the H. pylori status are not associated with significant histological changes in gastric mucosa. Despite a significant drop out of cases, among the cases followed up no significant progression in histological staging was seen during a one year follow-up. (JDigEndosc 2013;4(1):1-5)
\end{abstract}

Key Words: Gastric histology - Upper GI endoscopy-Omeprazole-Ranitidine - Gastric atrophy

\section{Introduction}

Proton pump inhibitors are among the most widely prescribed medications worldwide. It is the drug of choice in treatment of peptic ulcer disease and gastroesophageal reflux disease (GERD) with dramatic symptom response. Though these drugs are considered as safe, there are concerns in the present days on its long term safety. Reported adverse effects include B12 deficiency, bacterial overgrowth syndrome, increased risk of respiratory infections, clostridium difficile infection and bone fractures. ${ }^{1}$ Gastric mucosal changes have also been described which include occurrence of gastric fundic gland polyps, ${ }^{2,3}$ hyperplasia and hypertrophy of enterochromaffin cells. ${ }^{4}$ Parietal cell changes have been documented in children. ${ }^{5}$ Mucosal changes in the antrum and body of the stomach has also been reported. ${ }^{1,6}$ The

Reprints requests and correspondence:

V. Jayanthi,

Consultant Gastroenterologist and Hepatologist,

Global Health City, Chennai

Email: drjayanthi35@yahoo.co.in 
changes have been ascribed to high or low acid production, and presence or absence of $H$. pylori and non $H$. pylori infection. In patients who produce normal amounts of acid, H. pylori predominantly colonizes the gastric antrum resulting in antral predominant gastritis, while corpus predominant gastritis occurs in $H$. pylori colonizers with decreased acid production. ${ }^{7}$ Chourasia and others ${ }^{8}$ from north India documented gastric mucosal atrophy and intestinal metaplasia in a 74-year old male on a 20 -year PPI.

The risk of gastric cancer is not known. There are limited circumstantial data from both Japan and Europe that persistent corpus predominant gastritis and atrophy are major risk factors for the development of gastric cancer., ${ }^{9,10}$ Maastricht consensus panel recommends $H$. pylori eradication in patients who require long-term PPI therapy. ${ }^{1}$

With this background, we undertook the present study to characterize the histological changes in the antral mucosa in patients on long term proton pump inhibitor (omeprazole) and histamine 2 receptor antagonist (ranitidine) at baseline, at 6 and 12 months respectively $H$. pylori positive and negative patients.

\section{Methods}

\section{Inclusion and exclusion criteria}

Patients on long term maintenance with acid suppressants [Group I (ranitidine) and Group II (omeprazole)] for gastroesophageal reflux disease or dyspepsia from 2001 onwards and followed up until 2008 were included in the study. Patients on acid suppressants for less than a year and those on long term non steroidal anti inflammatory drugs (NSAIDs) were excluded from the study.

Details and duration of acid suppressants were noted. Patients who were willing to undergo an upper endoscopy with a follow up endoscopy at 6 months and 12 months were included in the study. Informed consent and patient's willingness to participate in the study was obtained. Ethics committee of the Institution approved the study.

\section{Grading and staging of gastric histology}

Baseline endoscopy findings were noted with emphasis on fundal polyps. Biopsy from the antrum along the lesser curvature, $1-2 \mathrm{~cm}$ proximal to the pylorus was obtained for histological staging; another sample was taken for $H$. pylori status. The grading and staging of gastritis ${ }^{11}$ was based on the severity of the inflammatory response and glandular changes. The findings were broadly classified as: (a) chronic active gastritis (CAG) - when inflammatory cells were present (mononuclear or granulocytic) with no glandular change;(b) atrophic gastritis(AG) -glandular change with inflammatory response; (c) intestinal metaplasia (IM) - when glandular changes in the antrum showed intestinal type of epithelium.

H. pylori eradication was achieved using a combination of omeprazole, amoxicillin and metronidazole for patients with a documented duodenal or gastric ulcer.

\section{Results}

There were 31 patients who were on ranitidine and 28 on omeprazole for over a year. The median age for patients on ranitidine was 47.5 years (range 22 to 70 years) and for those on omeprazole the median age was 45 years (range 18 to 70 yrs). There were slightly more men amongst omeprazole patients $(16 ; 57.1 \%)$ compared to ranitidine group (14; $45.2 \%)(p>0.05)$. The socioeconomic characteristics were similar in either group (Table 1).

Table 1: Demographic characteristics of patients on ranitidine and omeprazole

\begin{tabular}{|c|c|c|}
\hline & $\begin{array}{l}\text { Ranitidine } \\
\text { (31 cases) }\end{array}$ & $\begin{array}{l}\text { Omeprazole } \\
\text { (28 cases) }\end{array}$ \\
\hline Age (median) & $\begin{array}{c}47.5 \text { yrs } \\
\text { (range } 22 \text { to } 70 \text { yrs) }\end{array}$ & $\begin{array}{c}45 \text { yrs } \\
\text { (range } 18-70 \text { yrs) }\end{array}$ \\
\hline Gender, male:female & $14: 17$ & $16: 12$ \\
\hline Literacy status & $\begin{array}{l}\text { Illiterate: } 20 \\
\text { (64.5\%) }\end{array}$ & $\begin{array}{l}\text { Illiterate: } 17 \\
\text { (60.7\%) }\end{array}$ \\
\hline Per capita income & Rs.903/- & Rs.902/- \\
\hline Occupation & Laborers: 19(61.3\%) & Laborers: $17(60.7 \%)$ \\
\hline $\begin{array}{l}\text { Average duration } \\
\text { of medication }\end{array}$ & $\begin{array}{l}3 \text { years } \\
\text { (range } 1.5 \text { to } 8 \text { years) }\end{array}$ & $\begin{array}{c}4 \text { years } \\
\text { (1 to } 10 \text { years) }\end{array}$ \\
\hline H. pylori positive & $21(67.7 \%)$ & $24(85.7 \%)$ \\
\hline
\end{tabular}

H. pylori status prior to initiation of ranitidine or omeprazole in 2001 was not known. In 2008 when the prospective study was initiated the $H$. pylori status was as shown in Table 1. Since none of the patients included in the study had duodenal or gastric ulcer, no attempt was made to eradicate $H$. pylori. There was a high dropout rate despite initial consent for the study (34 patients at 6 months and 10 patients at 12 months). All these patients refused for a followup endoscopy, but continued to attend the GI dyspepsia clinic for medication.

\section{Gastric mucosal changes in patients on ranitidine}

The median duration of treatment with ranitidinewas 3 years (range: 1.5 to 8 years).

\section{H. pylori positive (21 persons)}

Figure1a shows the gastric mucosal changes at baseline, at 6 months and 12 months. Overall, 13 patients (CAG,8; AG,3; and IM, 2 at baseline) were followed up for 6 months and further 6 patients for 12 months ( 5 with CAG and 2 with AG dropped out). Only one patient with chronic active gastritis progressed to gastric atrophy. No progression of the mucosal changes was seen in patients with gastric atrophy or intestinal metaplasia.

\section{H. pylori negative (10 persons)}

Nine of the 10 patients had only chronic active gastritis. One patient followed up for 6 months, showed no histological progression (Figure 1b). 
Figure 1 a: Follow up 21 patients on ranitidine (H. pylori positive) Median duration of treatment: 3 years ( $1.5-8$ years)

\begin{tabular}{|c|c|c|c|}
\hline $\begin{array}{l}\text { Median duration } \\
\text { of ranitidine }\end{array}$ & 3 yrs $(1.5-8 y r s)$ & 5.5 yrs $(2-7 y r s)$ & $2 y r s, 7 y r s$ \\
\hline $\begin{array}{l}\text { Baseline } \\
\text { Drop out }\end{array}$ & $\begin{array}{c}\text { CAG: } 16 \\
\downarrow \\
8\end{array}$ & 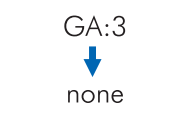 & $\begin{array}{l}\mathrm{IM}: 2 \\
\downarrow \\
\text { none }\end{array}$ \\
\hline $\begin{array}{l}\text { At } 6 \text { mo } \\
\text { Drop out }\end{array}$ & CAG: $7, \underset{\downarrow}{\downarrow}: 1 G: 3$ & 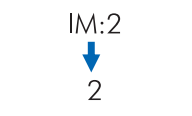 & $\begin{array}{l}\downarrow \\
\text { none }\end{array}$ \\
\hline At 12 months & CAG:2; GA: 1 & GA:1 & $\mathrm{IM}: 2$ \\
\hline
\end{tabular}

Figure 1 b: Follow up 10 patients on ranitidine (H. pylori negative) Median duration of treatment: 2.5 years ( $1-6$ years)

Median duration

Of ranitidine

Baseline

Drop out
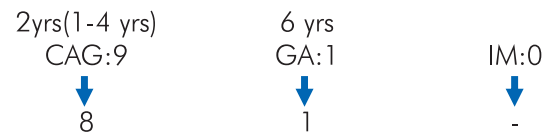

At 6 mo

Drop out
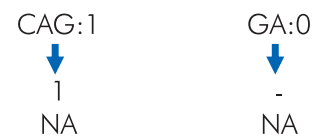

NA

At 12 months

NA

NA

NA

*CAG: Chronic active gastritis; GA: gastric atrophy; IM: Intestinal metaplasia

\section{Gastric mucosal changes in patients on omeprazole}

The median duration of treatment with omeprazole was 4 years (range 1 to 10 years).

H. pylori positive (24 persons)

Figure 2 a shows the gastric mucosal changes at baseline, at 6 months and 12 months. Ten of the 24 patients could be followed up for 6 months and 6 for 12 months. Three patients with CAG at baseline progressed to gastric atrophy; none of the patients with baseline gastric atrophy showed progression. Five of the 24 patients at baseline had intestinal metaplasia. At the end of a year, one progressed to dysplasia. One other patient with chronic gastritis at 6 months progressed to gastric atrophy at 12 months.

H. pylori negative (4 persons)

Figure 2a: Follow up 24 patients on omeprazole ( $H$. pylori positive) Median duration of treatment: 4 years ( 1 - 10 years)

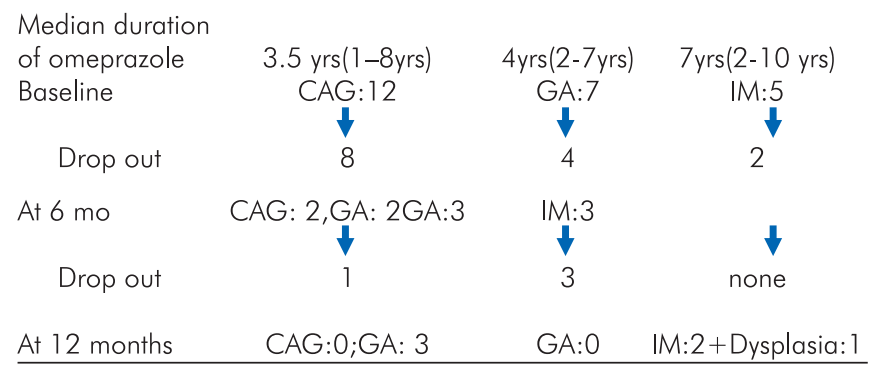

* CAG: Chronic active gastritis; GA: gastric atrophy; IM: Intestinal metaplasia
Figure 2b: Follow up 4 patients on omeprazole (H.pylori negative) Median duration of treatment: 3 years ( $2-7$ years)

\begin{tabular}{|c|c|c|c|}
\hline $\begin{array}{l}\text { Median duration } \\
\text { of omeprazole } \\
\text { Baseline } \\
\text { Drop out }\end{array}$ & $\begin{array}{c}4 y r s, 2 \text { yrs } \\
\text { CAG: } 2 \\
\downarrow \\
2\end{array}$ & $\begin{array}{c}2 \text { yrs, } 7 \text { yrs } \\
\text { GA:2 } \\
\downarrow \\
1\end{array}$ & $\begin{array}{c}\text { None } \\
\text { IM: NA } \\
\downarrow\end{array}$ \\
\hline At 6 mo & CAG: 0 & GA: 0, normal: 1 & NA \\
\hline Drop out & 1 & - & \\
\hline At 12 months & NA & GA: 0 & NA \\
\hline
\end{tabular}

*CAG: Chronic active gastritis; GA: gastric atrophy; IM: Intestinal metaplasia

Two patients each had CAG and AG. Only one patient with AG could be followed up for 6 months and his mucosa reverted to normal at 6 months. None of the four patients were available for follow up at one year.

Overall, in H. pylori negative patients, irrespective of the type of acid suppressant, none had baseline intestinal metaplasia. The baseline histology was either CAG $(78.5 \%)$ or GA $(21.5 \%)$. The median duration of ranitidine and omeprazole was 2.5 years (range 1 to 6 years) and 3 years (range 2 to 7 years) respectively.

In $H$. pylori positive group, two thirds of patients had CAG (ranitidine: $35.5 \%$; omeprazole: $26.6 \%$ ); 10 had gastric atrophy (ranitidine: 6.6\%; omeprazole:15.5\%) and 7 had intestinal metaplasia (ranitidine $4.4 \%$; omeprazole11.1\%). The median duration of $\mathrm{H} 2 \mathrm{RA}$ and omeprazole were 3 years (1.5 to 8 years) and 4 years (1 to 10 years) respectively. Four of the 10 patients on omeprazole showed progression of histology as against only one of the 13 on ranitidine.

\section{Discussion}

Gastric mucosal changes have been described in patients on long term acid suppressants. ${ }^{12}$ In an earlier study from our center, we had shown that long-term acid suppression therapy was associated with gastric mucosal changes mainly in the fundus and body. Histological progression correlated with increasing duration of omeprazole when compared to ranitidine. ${ }^{13}$ Haber et $a l^{14}$ in a multicenter study assessed the changes in gastric histology with long-term maintenance therapy with lansoprazole in patients with erosive esophagitis. The study consisted of an 8-week acute treatment period with lansoprazole, followed by a double-blind treatment with lansoprazole or ranitidine for up to 12 months, and then a titrated open-label maintenance therapy phase with lansoprazole for up to 82 months. Lansoprazole when administered as maintenance therapy for up to 6 years showed an improvement in chronic inflammation in the majority of patients, irrespective of baseline $H$. pylori infection status. No unexpected gastric pathology was noted.

The baseline histological changes were insignificant in our patients on ranitidine while intestinal metaplasia was seen more often in those on long term omeprazole, especially so if they were $H$. pylori positive. The progression of the 
disease was marked in the omeprazole group in our series compared to those on ranitidine. Earlier studies have shown that long-term use of omeprazoles does not decrease or accelerate the progression of pre-existing chronic gastritis, corpus gastric atrophy or intestinal metaplasia. ${ }^{12}$

Some patients refused to undergo repeat endoscopy, there was no significant histological changes seen in either group of patients who followed. However, one patient on long term omeprazole for more than 8 years had dysplasia.

Studies have shown differences in histology in $\mathrm{H}$. pylori positive and negative patients on long term omeprazole. In $H$. pylori negative persons, omeprazoles do not worsen pre-existing gastritis. ${ }^{15,16}$ and in fact there is an improvement of pre-existing gastritis. ${ }^{17}$ Atrophic gastritisis also not uncommon. ${ }^{18,19}$ Histological changes in $H$. pylori positive patients include acute or chronic gastritis, atrophy and metaplasiain the gastric corpus or antrum. ${ }^{16,18,20-22}$ Non progression of chronic gastritis to gastric atrophy, intestinal metaplasia, and gastric cancer has been reported. ${ }^{23}$ Studies have also shown H. pylori and omeprazoles may cause progression or acceleration from gastric antrumpredominant chronic gastritis to body-predominant chronic gastritis. ${ }^{24}$ H. pylori eradication may cause regression of gastric atrophy or intestinal metaplasia ${ }^{16,17,18,20,25-28}$ or may not. ${ }^{24,29-35}$ In view of the high prevalence rates of $H$. pylori and absence of duodenal or gastric ulcer, eradication of $H$. pylori was not attempted in our patients.

In our study, the $H$. pylori prevalence was as high as $85.7 \%$. The number of $H$. pylori negative were few. Hence the changes of gastric atrophy and intestinal metaplasia noted in this group could not be commented upon whether the mucosal changes were $H$. pylori related or related to prolonged acid suppressants.

The limitations of the study included significant number of dropouts both at 6 months and at 12 months in both groups of patients, largely due to non willingness to undergo repeat endoscopy procedure and biopsy, despite giving written consent at start of the study. The influence of H. pylori in this small series is not clear. Despite this, some useful information is forth coming on histological changes with long term use of acid suppressants in the small number of patients followed up for atleast a year. A one year follow up of patients on long term ranitidine irrespective of the H. pylori status, resulted in minor histological changes compared to omeprazole. Progression to intestinal metaplasia and even to dysplasia (one patient) was more common with omeprazole. The changes were predominant in patients with a treatment of 4 years or more and were noticeable at end of one year rather than at end of 6 months.

\section{Conclusions}

In conclusion, the results of this prospective follow up of a small series of cases with sequential gastric biopsies showed no major progression of mucosal changes in patients on long term acid suppressants be it ranitidine or omeprazole. The intestinal metaplasia seen with long term omeprazole may 'sound a warning' signal. It may be worth considering 'intermittent' or 'on demand' treatment in those requiring long term omeprazole. Multicenter studies in India with larger number of cases on long term follow up can throw more light on the recent observations in our study.

\author{
Acknowledgement \\ We thank Mr. Sri Hari, Junior Asst, Global Health City, Chennai \\ for technical assistance.
}

\section{References}

1. Ali T, Roberts DN, Tierney WM. Long term safety concerns with proton pump inhibitors. Am JMed 2009;122:896-903

2. Attard TM, Yardley JH, Cuffari C. Gastric polyps in pediatrics: an 18-year hospital-based analysis. Am J Gastroenterol 2002;97:298-301

3. Jalving M, Koornstra JJ, Wesseling J, Boezen HM, DE Jong S, Kleibeuker JH. Increased risk of fundic gland polyps during long-term proton pump inhibitor therapy. Aliment Pharmacol Ther 2006;24:1341-8.

4. Schenk BE, Kuipers EJ, Klinkenberg-Knol EC, Bloemena E, Nelis GF, Festen HP, et al. Hyper-gastrinaemia during longterm omeprazole therapy: influences of vagal nerve function, gastric emptying and Helicobacter pylori infection. Aliment Pharmacol Ther 1998;12:605-12.

5. Drut R, Altamirano E, Cueto Rúa E. Omeprazole-associated changes in the gastric mucosa of children.J Clin Pathol 2008; 61:754-6.

6. Geboes K, Dekker W, Mulder CJ, Nusteling K. Long term lansoprazole treatment for gastro-oesophageal reflux disease: clinical efficacy and influence on gastric mucosa. Aliment Pharmacol Ther 2001;15:1819-1826.

7. Sanduleanu S, Jonkers D, De Bruine A, Hameeteman W, Stockbrügger RW. Double gastric infection with Helicobacter pylori and non-Helicobacter pylori bacteria during acid-suppressive therapy: increase of proinflammatory cytokines and development of atrophic gastritis. Aliment Pharmacol Ther 2001;15:1163-75.

8. Chourasia D, Misra A, Pandey R, Ghoshal UC. Gastric atrophy and intestinal metaplasia in a patient on long term proton pum inhibitor therapy. Tropical Gastroenterology 2008; 29:172-4

9. Kuipers EJ. Proton pump inhibitors and gastric neoplasia. Gut 2006;55:1217-21.

10. Uemura $N$, Okamoto S, Yamamoto S, Matsumura $N$, Yamaguchi S, Yamakido M, et al. Helicobacter pylori infection and the development of gastric cancer. N Engl J Med 2001; 345:784-9.

11. Rugge M, Genta RM. Staging and grading of chronic gastritis. Human Pathology 2005;36:228 - 33.

12. Alan BR Thomson, Michel D Sauve, Narmin Kassam, Holly Kamitakahara. Safety of the long-term use of proton pump inhibitors. World J Gastroenterol 2010 ;16:2323-30.

13. Rajesh Prabhu P, Arunkumar K, Vimala R, Jayanthi V. Long term acid suppression therapy: its influence on gastric 
mucosa. Euroasian J Hepato Gastroenterol 2013;3:19-22.

14. Haber MM, Hunt B, Freston JW, Peura DA, Kovacs TO, Atkinson $\mathrm{S}$ et al. Changes of Gastric Histology in Patients with Erosive Oesophagitis Receiving Long-term lansoprazole maintenance Therapy. Aliment Pharmacol Therap 2010;32:83-96.

15. Diebold MD, Richardson S, Duchateau A, Bigard MA, Colin $\mathrm{R}$, Cortot A et al. Factors influencing corpus argyrophil cell density and hyperplasia in reflux esophagitis patients treated with antisecretory drugs and controls. Dig Dis Sci 1998;43: 1629-35.

16. Lundell L, Havu N, Miettinen P, Myrvold HE, Wallin L, Julkunen $\mathrm{R}$, et al. Changes of gastric mucosal architecture during long-term omeprazole therapy: results of a randomized clinical trial. Aliment Pharmacol Ther 2006;23:639-47.

17. Lamberts R, Brunner G, Solcia E. Effects of very long (up to 10 years) proton pump blockade on human gastric mucosa. Digestion 2001;64:205-13.

18. Kuipers EJ, Lundell L, Klinkenberg-Knol EC, Havu N, Festen HP, Liedman B et al. Atrophic gastritis and Helicobacter pylori infection in patients with reflux esophagitis treated with omeprazole or fundoplication. $N$ EnglJMed 1996;334:1018-22.

19. Lundell L, Miettinen P, Myrvold HE, Pedersen SA, Thor K, Andersson A et al. Lack of effect of acid suppression therapy on gastric atrophy. Nordic GERD Study Group. Gastroenterology 1999;117:319-26.

20. Kuipers EJ, Uyterlinde AM, Peña AS, Roosendaal R, Pals G, Nelis GF, et al. Long-term sequelae of Helicobacter pylori gastritis. Lancet 1995;345:1525-8.

21. Klinkenberg-Knol EC, Nelis F, Dent J, Snel P, Mitchell B, Prichard $\mathrm{P}$, et al. Long-term omeprazole treatment in resistant gastroesophageal reflux disease: efficacy, safety, and influence on gastric mucosa. Gastroenterology 2000;118:661-9.

22. Moayyedi P, Wason C, Peacock R, Walan A, Bardhan K, Axon AT, et al. Changing patterns of Helicobacter pylori gastritis in long-standing acid suppression. Helicobacter 2000;5:206-14.

23. Hirschowitz BI. Pernicious anemia and stomach cancer. Scand J Gastroenterol 2001;36:896.

24. Uemura N, Okamoto S, Yamamoto S, Matsumura N, Yamaguchi S, Mashiba Omeprazole, et al. Changes in Helicobacter pylori-induced gastritis in the antrum and corpus during long-term acid-suppressive treatment in Japan. Aliment Pharmacol Ther 2000;14:1345-52.
25. Ohkusa T,Fujiki K, Takashimizu I, Kumagai J, Tanizawa T, Eishi Y, et al. Improvement in atrophic gastritis and intestinal metaplasia in patients in whom Helicobacter pylori was eradicated.Ann Intern Med 2001;134:380-6.

26. Kuipers EJ, Nelis GF, Klinkenberg-Knol EC, Snel P, Goldfain $\mathrm{D}$, Kolkman JJ, et al. Cure of Helicobacter pylori infection in patients with reflux oesophagitis treated with long term omeprazole reverses gastritis without exacerbation of reflux disease: results of a randomised controlled trial. Gut 2004;53: $12-20$.

27. Kuipers EJ. Proton pump inhibitors and Helicobacter pylori gastritis: friends or foes? Basic Clin Pharmacol Toxicol 2006; 99: 187-94.

28. Malfertheiner P, Megraud F, O'Morain C, Bazzoli F, ElOmar E, Graham D, et al. Current concepts in the management of Helicobacter pylori infection: the Maastricht III Consensus Report. Gut 2007;56:772-81.

29. Robinson M. Drugs, bugs, and esophageal $\mathrm{pH}$ profiles. Yale J Biol Med 1999;72:169-72.

30. Stolte M, Meining A, Schmitz JM, Alexandridis T, Seifert E. Changes in Helicobacter pylori-induced gastritis in the antrum and corpus during 12 months of treatment with omeprazole and lansoprazole in patients with gastrooesophageal reflux disease. Aliment Pharmacol Ther 1998;12: 247-53.

31. McColl KE, Murray LS, Gillen D. Omeprazole and accelerated onset of atrophic gastritis. Gastroenterology 2000; 18:239.

32. McColl KE. Helicobacter pylori infection and long term proton pump inhibitor therapy. Gut 2004;53:5-7.

33. Gillen D, McColl KE. Problems associated with the clinical use of proton pump inhibitors. PharmacolToxicol 2001;89: 281-6.

34. Singh P, Indaram A, Greenberg R, Visvalingam V, Bank S. Long term omeprazole therapy for reflux esophagitis: followup in serum gastrin levels,EC cell hyperplasia and neoplasia. World J Gastroenterol 2000;6:789-92.

35. Ali T, Roberts DN, Tierney WM. Long-term safety concerns with proton pump inhibitors. AmJ Med 2009;122:896-903.

Source of support: Nil; Conflict of interest: none declared 